CATALAN REVIEW

Catalan Review

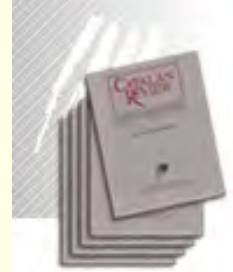

You are accessing the Digital Archive of the Catalan Review Journal.

By accessing and/or using this Digital Archive, you accept and agree to abide by the Terms and Conditions of Use available at http://www.nacs-

catalanstudies.org/catalan review.html

Catalan Review is the premier international scholarly journal devoted to all aspects of Catalan culture. By Catalan culture is understood all manifestations of intellectual and artistic life produced in the Catalan language or in the geographical areas where Catalan is spoken. Catalan Review has been in publication since 1986 .
NORTH

AMERICAN

CATALAN

SOCIETY
Esteu accedint a l'Arxiu Digital del Catalan Review

A l' accedir i / o utilitzar aquest Arxiu Digital, vostè accepta i es compromet a complir els termes i condicions d'ús disponibles a http://www.nacs-

catalanstudies.org/catalan review.html

Catalan Review és la primera revista internacional dedicada a tots els aspectes de la cultura catalana. Per la cultura catalana s'entén totes les manifestacions de la vida intel lectual i artística produïda en llengua catalana o en les zones geogràfiques on es parla català. Catalan Review es publica des de 1986.

\title{
On the Scent of Mary: The Power of Perfume in the Espill Lesley Twomey
}

Catalan Review, Vol. XX, (2006), p. 337-346 


\title{
ON THE SCENT OF MARY: \\ THE POWER OF PERFUME IN THE ESPILL
}

\author{
LESLEY TWOMEY
}

\begin{abstract}
This article examines Roig's use of perfumed items as a way of typifying the Virgin's immaculate nature. It examines how perfumes were embedded in early conception liturgies, particularly Leonardo de Nogarola's office, written with papal approval in the late i47os. Perfumes were used for a variety of reasons, such as in religious ceremonies, to embalm, and to adorn the bride for her nuptials. These uses are examined and their application to the nature of the Virgin determined. Finally, the uses of perfumes in Roig's household, for medical and household purposes, are described. The essay concludes that Roig may have been surrounded by the very perfumes he incorporates into his Espill, even as he wrote it.
\end{abstract}

The study of liturgical and poetic imagery I undertake in this essay is dedicated to the recognition of David Viera's outstanding research into religious writers in the kingdom of Aragon and particularly to his work on their approach to women (see Viera and Piqué). My approach to Jaume Roig's use of scent sets it in the context of pre-sixteenthcentury liturgies.' In the Espill, Jaume Roig associates Mary with sweet aromas of cinnamon, vine, and balsam:

\author{
Déu saludà \\ en lo mig jorn lo món entorn \\ tot, d'orient fins al ponent, \\ ab la sabor, suau olor \\ de tal canyella, sarment novella \\ de bàlsem planta, filla tan santa (16I)
}

In fact, this passage follows a section of the Espill, in which he praised the Virgin as sweet-smelling gum, whilst defending the Immaculate Conception. The possible meanings of this perfume will be drawn out as the second section of the essay:

1 I have used a corpus of eighty-two conception liturgies from across the Peninsula to determine how perfumes are used. My study excludes some breviaries still to see, at dace of writing, in Tarazona, Zamora, and Salamanca. I have excluded from the study eight further liturgies where the conception is mentioned but celebrated using another Marian feast, generally the Nativity. 


\author{
Déu sols n'absolta \\ De totes una, lluent com lluna, \\ Cintillant stella, més que cel cel-la, \\ Ab lo sol sola, com voltor vola, \\ Abella bella, ovella vella \\ E signat signe, fènix insigne \\ Colent coloma, ben olent goma [...]. (155)
}

Mary's conception has no mention in the Bible but supporters of the doctrine of the Immaculate Conception illustrated it by interpreting biblical figures according to their sensus mysticus (Tellechea Idigoras 19697; see also Auerbach). Marielle Lamy singles out Jean de Romiroy as one of the chief exponents of the technique. His treatise, written for the Council of Basle, pre-dated the Espill by just over twenty years. Lamy observes that Romiroy:

s'était appuyé sur l'Ecriture comme sur un repertoire de figures, parmi lesquelles il avait abondamment puisé pour exalter la sainteté sans faille de Marie: la femme écrasant la tête du serpent, la femme de l'A pocalypse ayant le soleil pour manteau et la lune sous ses pieds, mais aussi la vigne au parfum suave, l'arche en bois incorruptible, le cèdre et le cyprès imputrescibles, la myrrh, le jardin de roses, les lys au milieu des épines (tous ces elements vont bientôt constituer l'iconographie de l'Immaculée Conception), l'aurore qui se lève, l'étoile de la mer [...]. (16). [drew on Scripture, as if it were a repertoire of figures, which he mined to exalt the unblemished holiness of Mary: the woman crushing the head of the serpent, the woman of the Apocalypse with the sun as her cloak and the moon beneath her feet, but also the vine with soft perfume, the ark in incorruptible wood, cedar and cypress which never rot, myrrh, the garden of roses, the lily among thorns, the first signs of dawn, the star of the sea. Translations mine.]

Amid the series of prefigurations that are mentioned is the sweetscented vine, together with other aromatic plants, similar to Roig's.

The attributes of the female figures from the Old Testament, particularly of the Shulamite from the Song of Songs and of Wisdom, are staples of Marian liturgy: "Sicut mirra electa hodorem dedisti suauitatis sancta dei genetrix" [Like choice myrrh you gave forth an odour of softness, holy mother of God] is adapted from Ecclesiasticus 24.I5, in praise of Wisdom. ${ }^{2}$ It was used in the Little Office of the Virgin (Ricossa 58), and is generally present as an antiphon at first night prayer in conception offices. ${ }^{3}$ Juan de Segovia's office adapts it:

2 For a study of how attributes of Wisdom were applied to the Virgin Immaculate, see Twomey.

3 It is found in the Benedictine Diumale (ACB 22), in the Diumale monasticum (Montserrat $5 \mathrm{I}$ ), in the Osma Breviary $\left(\mathrm{ACBO}{ }_{2} \mathrm{~B}\right)$, and in the Breviarium gerundense (ACG 125). 
"Sicut mirra electa et aromatizans balsamum maria uirgo semper suauem diffundit odorem" (ACG I25, f.4v) [Just like choice myrrh and sweet-smelling balsam, Mary the ever-virgin exudes a soft perfume] (see also Ricossa 54). In a book of hours of the Virgin with Catalan rubrics, the comparison had been used as the third reading: "sic[ut] cinnamomum et balsamum aromatizans odorem dedi" (BL Addd.I8I93) [Like cinnamon and sweet smelling balsam I give forth odour]. The two plants are those that Roig will use. Mary's perfume is mentioned on no fewer than nineteen occasions at first night prayer in breviaries and devotional works: "germinauit enim florem qui uitalem dat hodorem" [the flower has bloomed which gives forth life-giving odour].4

At compline, the early fourteenth-century Girona office uses another text redolent of perfume from the Song of Songs: "Ista est que ascendit per desertum sic uirgula fumi ex aromatibus mirre et thuris et uniuersi pulueris pigmentarii" (ACG $125, \mathrm{f}_{35}$ or) [What is this coming up from the desert like a column of smoke, breathing of myrrh and frankincense and every exotic perfume?]. The same antiphon appears in Juan de Segovia's office, adopted in Girona (ACG I25, f, $7 \mathrm{r}$ ).

Of all the conception liturgies, Leonardo de Nogarola's (BC 1043), approved by Pope Sixtus in 1478, places most emphasis on Mary's perfumes, referring to them no fewer than nine times, and this without taking account of individual perfumes. The office associates scents with another prefiguration, the enclosed garden, which was applied first to her perfect virginity and later to her immaculate nature:

Emissiones tue paradisus: ortus delitiarium in quo sunt confita vniu[er]sa florum genera et odoramenta uirtutum. Sicque signatus ut nesciat uiolari neque corrumpi nullis insidiis fraudibusque diaboli. [Your scent is of paradise: a garden of delights in which is enclosed all types of flowers and fragrances of virtues. And so sealed that it may not be violated or corrupted by any of the traps or tricks of the devil] (BC 1043, f. 13v). ${ }^{5}$

The verses echo Song of Songs (4.12-14) [She is a garden enclosed, my sister, my promised bride; [...]. Your shoots form an orchard of pomegranate trees [...]; nard and saffron, calamus and cinnamon, with all the incense-bearing trees; myrrh and aloes with the subtlest odours].

${ }_{4} \mathrm{ACS} \mathrm{B}_{272}, \mathrm{ACS} \mathrm{B}_{288,} \mathrm{ACT} 33.6,33.7,33.9$, BN Res. 186, BN8902, BN9082, ACB 5t, $\mathrm{ACB}$ 22, $\mathrm{ACBO}_{2} \mathrm{~A}, \mathrm{ACC}_{17}, \mathrm{ACC}_{18}, \mathrm{BB}_{2}$, and Escorial A.III.14. It is also present in a small number of breviaries from the Kingdom of Aragon: ACSU incunable 147, AEV 82 and 83 .

5 The enduring quality of these verses to express Mary's sanctity and original purity is shown by response of the maculists. One hundred years later, P. Maldonado in his treatise against the Immaculate Conception dismissed it, arguing that the Fathers of the Church applied it indiscriminately to Mary, to the Church, or to the soul (Tellechea Idigoras 2ro). 
Although Nogarola's office does not refer to cinnamon, it may have been suggested to Roig by the biblical garden of delights.

Among the specific perfumes Nogarola uses is cedar, associated with purity and sinlessness: "et tigna domorum nostrarum cedrina: quoniam ambo sine macula" (f. 2ov): "compingamus illud tabulis [tabulis] cedrinis: omni puritatis odore repletis" [Let us construct it (the temple) with boards of cedar: full of the odour of purity]. In both cases cedar is associated with freedom from blemish and with sanctity. Nogarola is citing 1 Kings 6, and associating Mary with the construction of the temple by Solomon.

As well as echoing the Song of Songs and Wisdom literature, perfume could be considered appropriate as a descriptor of the Virgin, because of its purpose in religious ceremonies. Fragrance rises heavenward from the altar and mirrors the way the saint aspires to spiritual relationship with God (Dronke 77). It acts in application to the Virgin as a signifier of her perfect relationship with God.

According to Dentan in his commentary on the Song of Songs, "que est ista" and its column of incense suggests the coming of Yahweh (326). Since the New Testament coming of Christ was through Mary at the Incarnation, it suggests her flesh, a supreme example of consecrated matter (Boss 15, 77).

Another aspect of the use of perfumes and spices lies in the preparation of Mary's perfect body for nuptial unification with the deity. Bathing and adorning with perfumes indicates the initiation before consummation of a marriage (Merz I45). The perfuming of the body was another aspect of costly adornment alongside jewels and rich garments appropriate for a bride. In Mary's case, her assent at the Incarnation is often described as a betrothal and her conception and birth without sin form part of her adornment. Nogarola's office explicitly links perfume, purity, and nuptials:

Dum esset rex in a[c]cubitu suo: nardu[s] nostra dedit odore[m] suauitatis: nardus humilis satis herba; humilis maria odore[m] dedit; mea carissima que ex [fasciculo] mirre reseruata est ex mei morte dilecti filii sui congerie passionis nostre. Qui mirra et aloe perlinit[us] fui; qui inter ubera commemoratus est; (BC I043, f.20v; BUZ incunable 60, f.373v). [Whilst the king was in his chamber, nard gave sweet perfume: nard is a humble herb; humble Mary gives forth a sweet odour; my dearest is reserved from a bundle of myrrh, from the death of my dear son, from his accumulation of our passion. He reclined with myrrh and aloe; and he recalled being on her breast.]

In the Espill, Jaume Roig praises Mary, the perfect bride, for her scent of cinnamon and balsam. Other women, like Roig's wife, spend time at their toilette to try to improve their natural odour, whilst Mary is attractive to God because of her odour of sanctity. Roig's wife 
perfumes herself before matins: “Ans de matines/ Ella's llevava i 's perfumava / fent-se ben olre" (59). The emphasis Roig places on elimination of smelly bodily odours and adding perfume, adorning oneself because of being sexually available, is devised as a contrast between Mary's perfection and other women's faults. ${ }^{6}$

Some of the biblical and liturgical perfumes, like myrrh, were used for preservation of the body following death, and their connection with non-corruption and with conservation led to initial association with the Assumption of the Virgin and then by extension to other aspects of her preservation from corruption, like her immaculacy. This meaning is drawn out by the certamen poet Narcís Vinyoles who points to Mary's preservation from sin by the myrrh of love: "Mirra d'amor vos ha tant conservada" (in Ferrando Francés 287, 11. 3-4). From death, the perfumes shifted easily to referring to the death of $\sin$ and to embalming or preservation from it.

To categorize Mary's immaculate nature, Roig selects a series of natural elements, including birds, celestial bodies, and then evokes the Virgin's perfume in "olent goma". In order to establish what Roig means by "goma," I will examine some of the properties of aromatic plants.

"Ben olent goma" may be a reference to myrrh. Myrrh is present in conception liturgies, and in Larousse's encyclopaedia of perfumes it is described as one of the resinoids, which fix perfumes (149). It is used in Proverbs 7:17 as the perfume used for the marriage bed. It was also used in medieval times as an antiseptic and it is probable that, as a doctor, Roig was used to handling it.

He may also be referring to incense. The column of incense is present in liturgies and according to Isidore of Seville, it is:

Tus arbor Arabiae inmensa atque ramosa lenissimi corticis, ramis ad aceris qualitatem, amygdalae modo sucum aromaticum fundens album et masticatione veluti in pulverem resolutum, et cum frangitur, intus pingue et igni adpositum facile ardescens. Et appellatur apud nos masculum, eo quod sit natura rotundum in modum testiculorum. (1187-9)

árbol de Arabia de enorme corpulencia, dotado de abundantes ramas, de una corteza muy suave; sus ramas se asemejan a las del arce; destila un jugo aromático blanco, a manera de almendra; $[\ldots]$ puesto en el fuego arde fácilmente. Entre nosotros se denomina masculum por su conformación redonda, a modo de testículos [...]. Se adultera mezclándolo con resina o goma, pero se le reco-

6. Archer does not consider that Roig contributed to any kind of misogynist debate in Valencian letters but merely that he followed traditional sources which denigrate women $(10,19)$. His conclusions are at odds with those of previous commentators on the debate about women, including Rosanna Cantavella, who has seen the Valencian debate as an extension of the French one ("Els cards" 20; "Isabel de Villena"; "Debate on Women"). 
noce por su propiedad, pues el incienso puesto en el fuego arde, la resina provoca humo, y la goma al calentarse, se licúa".

Although Isidore describes incense as a "juice" he also says it has an almond shape. The mixing with gum or resin which he describes might make it also a candidate.

There are other contenders. Isidore also describes the use of cedar, another of the biblical perfumes as described above and a resinoid perfume, and associates it with preservation:

Lignum vero iucundi odoris estet diu durans, nec a tinea umquam exterminatur: unde et in templis propter diuturnitatem ex hoc ligno lacunaria fiunt. Huius lignium cedria dicitur, quae in conservandis libris adeo es utilis ut perliniti ex ea nec tineas patiantur nec tempore consenescant ( $1178-79$ ).

[...] al cedro los griegos lo denominan kedros [...] su madera es de agradable olor y dura mucho tiempo, y nunca es atacada de carcoma. Debido a su durabilidad de esta Madera se construyeron los artesonados de los templos. La resina de este árbol se conoce con el nombre de cedria, y resulta tan útil para conservar los libros que, cuando se los barniza con ella, no sufren la acción de las polillas ni envejecen con el tiempo (7-7).

Could it be to cedar that Roig is referring when he describes Mary as a gum? It would have been particularly applicable to her because of its incorruptibility. In his description, Isidore mentions its resin, which, according to him, has a practical application in preserving books and it continues today to be recommended on the internet as a substance which will prevent moth damage, although only aromatic or incense works, not the standard type. Perhaps Roig was aware of the substance, using it for his own books.

Perfumes were also in constant use in households such as Roig's, and the scents he used to depict the Virgin would have been familiar. Housewives made their own perfumes, as is shown by a sixteenthcentury book of recipes for preparing scents for sprinkling on clothes and rubbing on gloves. The recipe for making musk water includes the use of two resinous perfumes, musk and ambar:

Para azer agua amizcada

A quatro libras de agua rosada dos libras de flor de mosqueta vna libra de azar de açuçenas toda buelta en vna redoma y tomar quatro onças de benjuy y molello y echallo en una redoma y una cuarta destoraque y vna cuarta de anbar y media cuarta de almizque y tanto como media avellana de algalia y echar la mitat dello en vna caldera de agua y ponello al fuego y yerua media ora y apartalda y ansi dentro enla caldera de que se vaya enfriando sacar la pasta para azer panezitos y el agua pasalla a otra redoma y moler la mitat del anbar y el almizque que quedo y echarlo dentro y algalia y desatalla con poluillos y 
echarlo dentro y tenello bien atapado y de que quieran sacar della menealla dentro en la redoma (f, $132 \mathrm{v}$ ).

The recipe book is from the sixteenth century but Roig's wife would have been using these or similar recipes in their household to perfume the linen, the gloves, and the clothing. Sprinkling with rosewater or musk-water made the perfect alternative to laundering. It is not impossible that the "ben olent goma," which Roig mentions, is ambar or musk, and was suggested to him, as he wrote the Espill, by the scent of home-made pertumes which his wife was preparing.

In this essay I have shown that Roig follows the liturgies of his day as he applies perfumes to the Virgin to exemplify her Immaculate Conception. Donna Spivey Ellington argued that "use of the Song of Songs as a source of Marian allegory in sermons and Biblical exegesis was first inspired by the book's use to praise Mary in the liturgy" (61).? But her assessment should be amended on two counts. First, its use in literature was inspired by the liturgy too. Second, to her point that the Song of Songs provided sermon writers, exegetes, and poets with material should be added Wisdom literature, like the passage from Ecclesiasticus examined earlier.

But at the same time the choice of perfumes, particularly the "olent goma" to which he compares her, may have been suggested also by familiar scents in his home, as he wrote. The scent of household objects is particularly evocative. If it were these Roig is recalling, it would turn his use of perfume as a negative comparator for women inside out. At the same time as using perfume to elevate the Virgin above all others, could he be subtly evoking the work of the diligent housewife, his wife, whose task is to perfume the objects in everyday use in his home?

LESLEY TWOMEY NORTHUMBRIA UNIVERSITY

7 This is true but the time-scale she suggests for it is wide of the mark. She notes a two-hundred-year tradition of allegorizing it to represent the relationship between Jesus and Mary by the time of Jean Gerson (d.r.429). Other scholars point to different starting points. Hilda Charlotte Graef argues that Ambrose was the earliest (83), whilst E. Ann Matter held that the Song of Songs had first been applied to Mary in the liturgy in the seventh century and she notes a ninth-century Marian commentary, Cogitis me, by Paschasius Radbertus, which makes an important connection between the Song of Songs and Mary's Assumption (151-55). She later indicates that it was with Rupert of Deutz (b.1075) that Marian commentary on the Song really began (159). 


\section{WORKS CITED}

ARCHer, Robert. The Problem of Woman in Late Medieval Hispanic Literature. Colección Tamesis, Serie A, Monografías, 214. Woodbridge, Suffolk: Boydell \& Brewer, 2005.

AuERBACH, Erich. "Figura," in Scenes from the Drama of European Literature. Tr. R. MANNHEIM, Theory and History of Literature, 9. Manchester: Manchester UP, 1985. II-76. (Tr. of "Figura," Neue Dantestudien, Istanbul, 1944, II-71; Repr. "Figura", Archivum Romanicum 22 (1938): 436-89.)

Boss, Sarah Jane. Empress and Handmaid: On Nature and Gender in the Cult of the Virgin Mary. London: Cassell, 1999.

Cantavella, Rosanna. "Debate on Women in Tirant lo Blanch." In The Querelle des Femmes in Romania: Studies in Honour of Friederike Hassauer. Eds. Wolfram AICHINGER, Marlen BIDWELLSTEINER, Judith BösCH and Eva CESCUTTI. Vienna: Turia \& Kant, 2003. $45-56$.

-. "Els cards i el llir: una lectura de l'Espill de Jaume Roig." Assaig. Barcelona: Quaderns Crema, 1992.

-. "Isabel de Villena." In Iris M. ZAVALA, ed. Breve historia feminista de la literatura española (en lengua catalana, gallega y vasca). VI, Cultura y Diferencia: Teoría Feminista y Cultura Contemporánea, Pensamiento Crítico \& Pensamiento Utópico, II2. Barcelona: Antropos, 2000. 40-50.

DenTAN, Robert C. "The Song of Solomon." In The Interpreter's One-Volume Bible Commentary on the Bible: Introduction and Commentary for Each Book of the Bible including the Apocrypha, with General Article. Ed. Charles M. LAYMON. $13^{\text {th }}$ ed. Nashville, TN: Abingdon Press, 1991. 324-28.

Dronke, Peter. The Medieval Lyric. $2^{\text {nd }}$ ed. London: Hutchinson, 1978. Ellington, Donna Spivey. From Sacred Body to Angelic Soul: Understanding Mary in Late Medieval and Early Modern Europe. Washington, DC: Catholic U of America P, 20or.

FERRANDO FrANCES, Antoni. Els certàmens poetics valencians del segle XIV-XIX. Institut de Literatura i Estudis Filològics. València: Institució Alfons el Magnànim \& Diputació de València, 1983.

Graef, Hilda Charlotte. Mary: A History of Doctrine and Devotion. 2 vols. London: Sheed \& Ward, 1963-65.

IsIDORE OF SEVILLE. Etimologias: edición bilingüe, ed. José OROZ Reta, Manuel-A. MARCOS CASQUero, with introduction by Manuel C. DfAz y Díaz. Madrid: Biblioteca de Autores Cristianos, 2004.

LAMY, Marielle. L'Immaculée Conception: étapes et enjeux d'une controverse au Moyen Âge (XII ${ }^{e}-X V^{e}$ siècles). Collection des Etudes 
Augustiniennes, Série Moyen Âge et Temps Modernes, 35. Paris: Institut d'Etudes Augustiniennes, 2000.

Larousse del perfume y las esencias. Barcelona: Larousse, 2000.

MATTER, E. Ann. The Voice of My Beloved: The Song of Songs in Western Medieval Christianity. Repr. 1990 ed. Philadelphia: U of Pennsylvania $\mathrm{P}$, 1992.

Merz, Annette. "Why did the Pure Bride of Christ (2.Cor. Ir.12) become a Wedded Wife (Eph 5.22-33)? Theses about the Intertextual Transformation of an Ecclesiological Metaphor." Journal for the Study of the New Testament, 79 (2000). 131-147.

Ricossa, Luca Basilio. Jean de Ségovie: son office de la Conception. Étude historique, théologique, littéraire et musicale, Série XXXVI, Musicologie, 113. Bern: Publications Universitaires Européennes, 1994 .

RoIG, Jaume. Espill o Llibre de les dones. Ed. Marina GuSTÀ. Les Millors Obres de la Literatura Catalana, 3. Barcelona: Edicions 62 i "La Caixa," 1978.

Tellechea Idigoras, José Ignacio. La Inmaculada Concepción en la controversia del P. Maldonado, S. J. con la Sorbona. Vitoria: Seminario, 1958.

TwOMEY, Lesley K. The Serpent and the Rose. Leiden: Brill, in press. VIERA, David and Jordi PIQUEE. La dona en Francesc Eiximenis. Barcelona: Curial, 1987.

WARNER, Marina. Alone of All her Sex: The Myth and Cult of the Virgin Mary. London: Weidenfeld \& Nicolson, 1976.

\section{Primary Sources}

Abadía de Montserrat (Montserrat) 830, Varia ascetica.

Archivo de la Catedral de El Burgo de Osma, (ACBO) $2 \mathrm{~A} \& 2 \mathrm{~B}$, Breviario de Osma.

Archivo de la Catedral de Burgos (ACB) 22, Diurnale benedictino.

Archivo de la Catedral de Calahorra (ACC) ${ }_{17}$, Breviario de Calahorra. Archivo de la Catedral de Calahorra (ACC) 18, Breviario de Calahorra.

Archivo de la Catedral de Segovia (ACS) B288, Breviarium secundum consuetudinem ecclesie segobiensis,

Archivo de la Catedral de Segovia (ACS) B 272 , Breviarium secundum consuetudinem ecclesie segobiensis.

Archivo de la Catedral de Toledo (ACT) 33.6, Breviaria de Toledo. Archivo de la Catedral de Toledo (ACT) 33.7, Breviario de Toledo. Archivo de la Catedral de Toledo (ACT) 33.9, Breviario de Toledo. Arxiu de la Catedral de La Seu d'Urgell (ACSU) incunable 147 
Arxiu de la Catedral de Girona (ACG) 125, Breviarium gerundense. Arxiu Episcopal de Vich (AEV), 82, Breviarium sedis vicensis Arxiu Episcopal de Vich (AEV), 83 Breviarium secundum usum barcinonensis

Biblioteca Balaguer, Vilanova i La Geltrú (BB) 2, Breviario de Toledo. Biblioteca de Catalunya (BC), 1043, Officium immaculatae conceptionis Biblioteca de la Abadía de Monserrat (Montserrat) 5I, Diumale monasticum

Biblioteca nacional (Madrid) (BN) Res. 186 , Breviario romano y suplemento al uso de la Orden de los Jerónimos.

Biblioteca nacional (Madrid) (BN) BN 9082, Breviario romano adaptado al uso de la Orden de los Jerónimos.

Biblioteca nacional (Madrid) (BN) BN 8902, Breviario de Toledo adaptado al uso del convento de Uclés.

British Library (BL) Add.r8193, Book of Hours in Latin with Spanish Rubrics in the Catalan Dialect, Les hores. e offici de nostra senyora, segons la esglesia romana.

Monasterio del Escorial (Escorial) A.III.14, Breviarium fratrum minorum secundum consuetudienem curiae romanae 